\title{
The Employment and Earnings of Female Workers at the Construction Site of Himlam Project, Tan Hung Ward, District 7, Ho Chi Minh City
}

\author{
Doan Van Thang* \\ Ton Duc Thang University, Ho Chi Minh City, Vietnam
}

*Corresponding Author: Doan Van Thang, Ton Duc Thang University, Ho Chi Minh City, Vietnam

\begin{abstract}
In recent years, female workers have made great contribution into the socio-economic development in our country. However, they still have to face many difficulties in finding a stable job. Their earnings are also much lower than male workers. This paper aims to study the employment and earnings of female workers at the construction site of Himlam project, Tan Hung Ward, District 7, Ho Chi Minh city
\end{abstract}

Keywords: female migrant workers, employment, income, Himlam construction site

\section{INTRODUCTION}

Ho Chi Minh City has more than 1 million workers working in enterprises and industrial parks, of which more than $70 \%$ are migrant workers. According to the a survey conducted by the author in the construction enterprises of Himlam project, all enterprises have a tendency to use simple, low-skilled or unskilled labor. This is an opportunity for workers, especially female workers, who migrate from rural areas to the city to find work and get access to social services in their lives.

Him Lam Kenh Te project is invested by Him Lam Trading Co., Ltd. The project is located in front of North-South Highway, near Kenh Te Bridge, in Tan Hung Ward, District 7, Ho Chi Minh City. It is only $3 \mathrm{~km}$ from Ben Thanh market and $1 \mathrm{~km}$ from Phu My Hung new urban area, located on the intersection of main roads such as Nguyen Van Linh avenue, Nguyen Thi Thap street, Khanh Hoi street, Le Van Luong street, thereby linking districts 1, 4, 7, Binh Chanh and Nha Be district. Currently, the construction site of Himlam project in Tan Hung ward, District 7, Ho Chi Minh City, has a total of 317 workers working at the construction site, including 133 female and 184 male workers; 224 workers are married and 93 are unmarried; 74 people are permanent residents in Ho Chi Minh City and 234 people living outside the city;

This study examines the employment and earnings of female migrant workers at the construction site of Himlam project

\section{EMPLOYMENT}

Most construction workers are unskilled laborers in the field of construction. In a survey conducted by the author, their employment consists of the work of the main workers and auxiliary workers, as shown in the following chart:

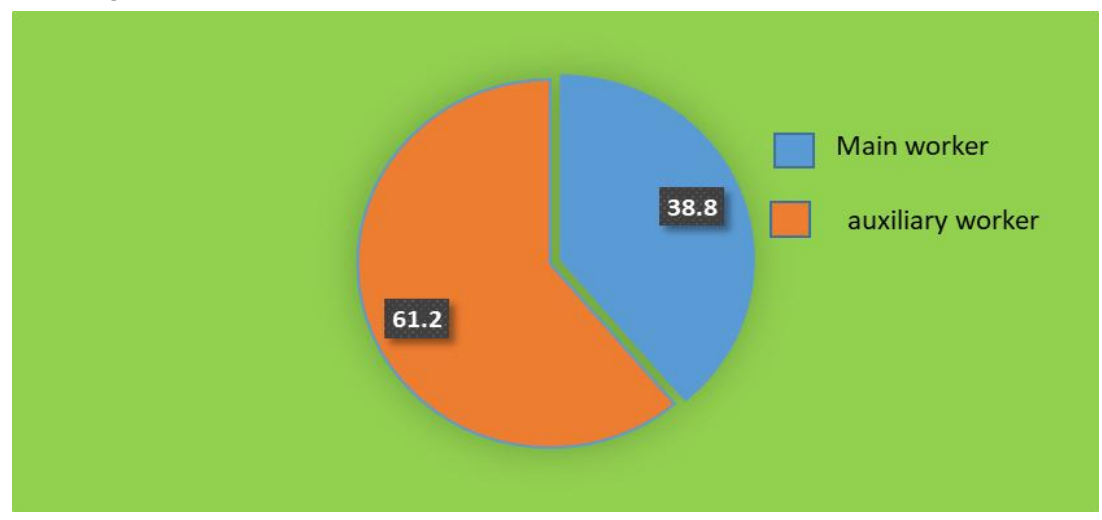


The diagram shows that on Himlam construction site, overall, among 317 workers, $61 \%$ are auxiliary workers and 39\% are main ones. The work of the main workers includes building, painting, ceiling installation, installation of electrical and water equipment. Auxiliary workers usually undertake the main tasks such as carrying water, mixing mortars, carrying bricks, digging soil, carrying trees, bricks and tiles, carrying iron sheets, and whitewashing. The following table shows the proportion of main and auxiliary workers according to gender:

Table1: Construction work according to gender

\begin{tabular}{|c|c|c|c|c|c|c|}
\hline \multirow{3}{*}{ Construction worker } & \multicolumn{6}{|c|}{ Sex } \\
\hline & \multicolumn{2}{|c|}{ Male } & \multicolumn{2}{|c|}{ Female } & \multicolumn{2}{|c|}{ Total } \\
\hline & $\mathrm{n}$ & $\%$ & $\mathrm{n}$ & $\%$ & $\mathrm{n}$ & $\%$ \\
\hline Main worker & 118 & 88.7 & 5 & 2.7 & 123 & 38.8 \\
\hline Auxiliary worker & 15 & 11.3 & 179 & 97.3 & 194 & 61.2 \\
\hline Total & 133 & 100.0 & 184 & 100.0 & 317 & 100.0 \\
\hline
\end{tabular}

Source: A survey of the author

With regard to gender, Table 1 illustrates that there are differences in employment between men and women. In indicator 1, for the main worker, it shows that the male workers accounted for the highest proportion of $88.7 \%$, compared to the female ones of $2.7 \%$. On the contrary, in indicator 2 , for auxiliary workers, it indicates that the male workers represented only $11.3 \%$ while female ones represented $97.3 \%$. We can see that the number of male workers as main workers is much higher than female ones. For auxiliary workers, the number of female workers is higher than male workers. It is often thought that heavy work is done by men. But this survey proves that hard work such as mixing mortars, carrying bricks, etc. are also done by women. To find out more deeply about this issue, the author interviewed a female auxiliary worker and she answered that "I can earn very little with growing rice, so I decided to move to Ho Chi Minh city to work. The work is really hard, but I can earn more money".

Regarding marriage status, there is a difference among married and unmarried groups. In indicator 1 , for main workers, the percentage of married workers is $30.8 \%$, lower than the proportion of unmarried ones, that is $58.1 \%$. In contrast, for auxiliary workers, the proportion of married workers is $69.2 \%$, higher than the proportion of unmarried workers, that is $41.9 \%$.

Regarding household registration, in indicator 1, the main workers have household registration in Ho Chi Minh city accounted for $89.2 \%$, compared to workers having household registration outside the city is $23,5 \%$. In indicator 2, auxiliary workers have household registration in Ho Chi Minh City only accounted for $10.8 \%$ while those with household registration outside the city accounted for a relatively high proportion of $76.5 \%$. In addition, there are also big differences between groups in terms of age and education level.

\section{SENIORITY}

Working time to calculate severance pay is the total time that workers actually work for their employers under signed labor contracts (including oral contracts). Through the author survey, this can be seen in Table 2 as follows:

Table2: Seniority according to gender

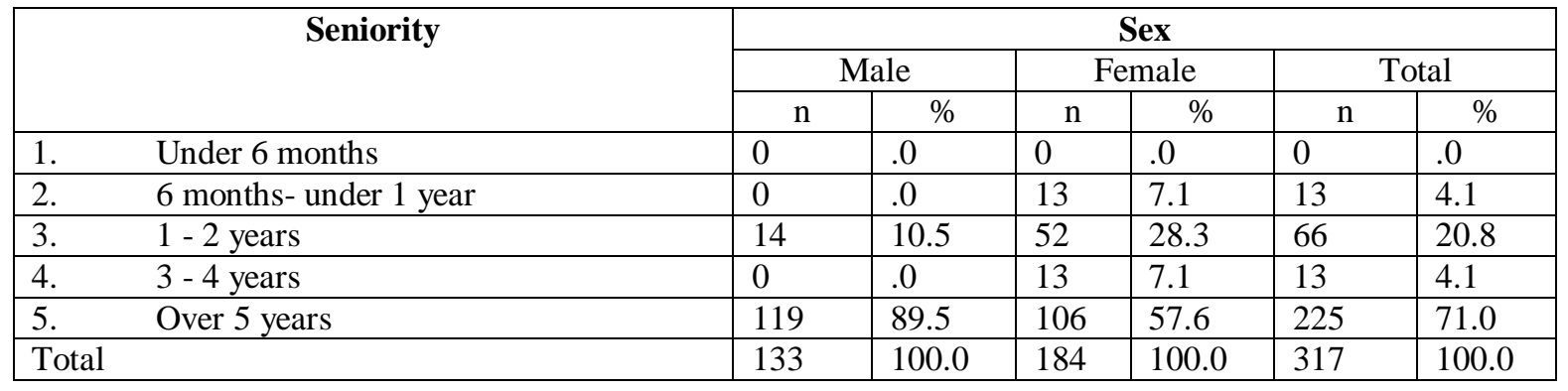

Significant $=0.000$

Source: The survey of the author 
At present, the number of long-term workers working for companies on Himlam construction site for more than 5 years accounted for the highest proportion of $71 \%$ compared to $21 \%$ working for $1-2$ years and less than 6 months and 4\% working for 3-4 years.

When comparing between social groups, we can see many differences between groups. Regarding gender, in indicator 5, there is a big difference between male and female group in the seniority of more than 5 years. The male group currently accounted for $89.5 \%$, higher than the female group which accounted for $57.6 \%$. However, in indicator 3, with the seniority of 1-2 years, the female group accounted for $28.3 \%$, higher than the male group which only accounted for $10.5 \%$. It proves that that female workers with 5 years and over 5 years of seniority accounted for a low proportion. Female workers with 1 or 2 years of seniority have the higher proportion. To study deeply about this issue, the author interviewed a male and a female worker at Himlam construction site.

\subsection{The Reason why the Female Workers on the Himlam Site have Short Seniority}

"I have been working on this construction site for 6 years. It is a very hard work, so many female workers can only work for only few months or years and try to find another job to do" (a female 37 year- old worker).

"This is hard manual work so many women cannot bear it. Moreover, they have to look after their children, so they have to find anther job to do" (a male 40 year-old worker)).

\section{Source: A survey of the author}

Regarding marriage status, in indicator 2 and 3, married workers have a lower proportion of seniority than unmarried ones. In indicator 5 , with seniority of over 5 years, there is no significant difference between two groups

And with regard to permanent residence, workers with household registration in the provinces have the lower level of seniority than workers with household registration in Ho Chi Minh city. To study the cause of this issue, the author interviewed a male and a female worker. The male 39 year- old worker answered that "I only worked here for a few years, then I went back to my hometown to live because my house, my children, my parents were there". The female worker answered "I am reluctant to come here to earn money to support my children. When my children finish college, I will return to my hometown". Besides, in terms of education level and age group, there is a relatively big difference in seniority among workers on Himlam construction site at present

\section{JOB STABILITY}

Income is an expression of whether the job is stable or not. The results of the survey conducted with 317 workers on Himlam constructions are shown in the following chart:

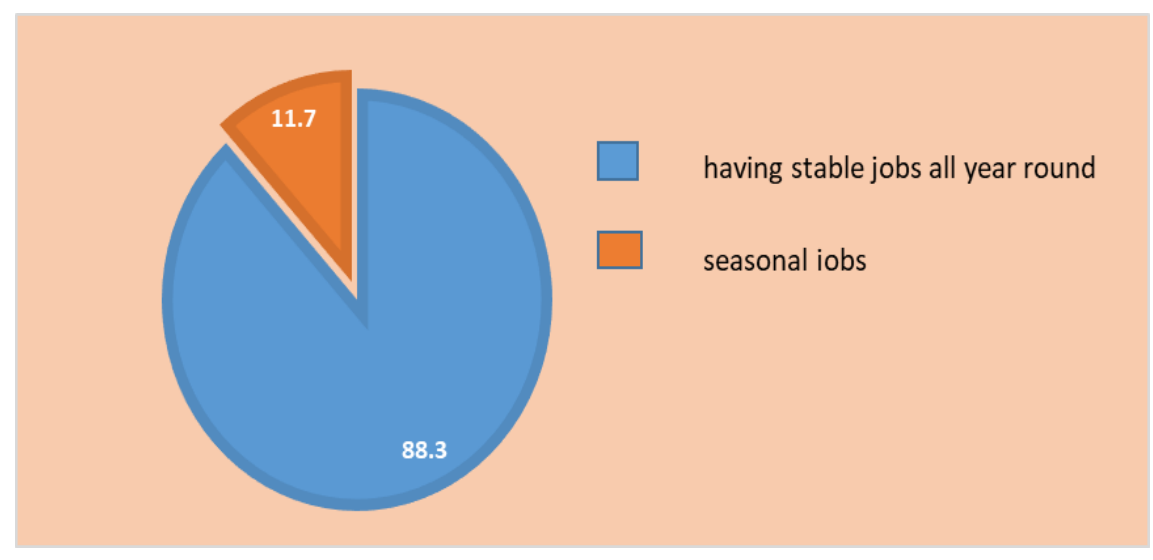

Chart2: Job stability of workers at Himlam construction site

Source: The survey of the author

The chart above shows that workers of companies at Himlam construction site have relatively stable jobs accounting for $88 \%$, only $12 \%$ doing seasonal jobs. 
The Employment and Earnings of Female Workers at the Construction Site of Himlam Project, Tan Hung Ward, District 7, Ho Chi Minh City

When comparing between social groups, it shows that each group has similarities or differences:

Table3: Job stability according to gender

\begin{tabular}{|l|l|l|l|l|l|l|l|}
\hline \multirow{2}{*}{ Job stability } & \multicolumn{4}{c|}{ Sex } \\
\cline { 3 - 8 } & & \multicolumn{2}{|c|}{ Male } & \multicolumn{2}{c|}{ Female } & \multicolumn{2}{c|}{ Total } \\
\cline { 3 - 8 } & & $\mathrm{n}$ & $\%$ & $\mathrm{n}$ & $\%$ & $\mathrm{n}$ & $\%$ \\
\hline 1. & Having a stable job all year round & 115 & 86.5 & 165 & 89.7 & 280 & 88.3 \\
\hline 2. & Seasonal work & 18 & 13.5 & 19 & 10.3 & 37 & 11.7 \\
\hline Tống & 133 & 100.0 & 184 & 100.0 & 317 & 100.0 \\
\hline
\end{tabular}

Source: A survey of the author

Regarding gender, the above table shows that there are similarities in job stability between men and women. Male workers having a stable job all year round accounted for $86.5 \%$ and female workers accounted for $89.7 \%$. Male seasonal workers represented $13.5 \%$ while female seasonal workers represented $10.3 \%$.

Regarding marriage status, there is big a difference between two groups. In indicator 1, married workers having a stable job all year round accounted for $94.2 \%$ while single workers accounted for $74.2 \%$. On the contrary, in indicator 2 , single workers having seasonal work accounted for $25.8 \%$ while unmarried workers represented $5.8 \%$. To find the cause for this issue, the author interviewed a male 44- year- old worker and he answered: "I want a stable job because it will help me to have stable income to support my family".

Regarding household registration, there is also a big difference between two groups. In indicator 1, the group with household registration outside Ho Chi Minh city having a stable job all year round accounted for $95.1 \%$, much higher than the group having household registration in Ho Chi Minh city, with only $66.2 \%$. In contrast, in indicator 2 , the group with household registration in Ho Chi Minh city having seasonal work accounted for $33.8 \%$ while group with household registration outside Ho Chi Minh city accounted for $4.9 \%$. In order to study this issue, the author interviewed a male 38-yearold worker having household registration outside Ho Chi Minh city and his answer is: "I decided to come here from Soc Trang to find a stable job to support my children at home".

In terms of the age group and education level, there are also great differences between the groups in the stability of workers' job.

\section{EMPLOYMENT CONTRACTS}

In recent years, the operation of enterprises has obtained outstanding achievements, contributing to the liberation and development of production capacity, mobilization and promotion of internal resources in socio-economic development, increasing export turnover and addressing effectively social problems such as creating jobs and poverty eradication. First of all, in order to ensure the rights and obligations of employees in the enterprises, the State has played an important role in implementing social policies for workers. So far, the State has issued many types of documents regulating the implementation of social policies for workers, according to the process of building the legal system.

Table4: Employment contracts according to seniority of workers

\begin{tabular}{|c|c|c|c|c|c|c|c|c|c|c|c|c|}
\hline \multirow[t]{3}{*}{ Employment Contract } & \multicolumn{12}{|c|}{ Seniority } \\
\hline & \multicolumn{2}{|c|}{$\begin{array}{l}\text { Under } 6 \\
\text { months }\end{array}$} & \multicolumn{2}{|c|}{$\begin{array}{c}\text { 6months- } \\
\text { under } 1 \text { yesr }\end{array}$} & \multicolumn{2}{|c|}{$1-2$ years } & \multicolumn{2}{|c|}{$3-4$ years } & \multicolumn{2}{|c|}{ Over 5 yeras } & \multicolumn{2}{|c|}{ Total } \\
\hline & $\mathrm{n}$ & $\%$ & $\mathrm{n}$ & $\%$ & $\mathrm{n}$ & $\%$ & $\mathrm{n}$ & $\%$ & $\mathrm{n}$ & $\%$ & $\mathrm{n}$ & $\%$ \\
\hline $\begin{array}{l}\text { 1. An indefinite term contract } \\
\text { (or over } 36 \text { months) }\end{array}$ & 0 & .0 & 0 & .0 & 0 & .0 & 0 & .0 & 0 & .0 & 0 & .0 \\
\hline $\begin{array}{l}\text { 2. Definite term contract (between } \\
12 \text { months and } 36 \text { months) }\end{array}$ & 0 & .0 & 0 & .0 & 0 & .0 & 0 & .0 & 0 & .0 & 0 & .0 \\
\hline $\begin{array}{l}\text { 3. A seasonal contract (under } 12 \\
\text { months) }\end{array}$ & & .0 & 0 & .0 & 26 & 39.4 & 13 & 100.0 & 26 & 11.6 & 65 & 20.5 \\
\hline 4. $\quad$ Verbal agreement & 0 & .0 & 13 & 100.0 & 27 & 40.9 & 0 & .0 & 186 & 82.7 & 226 & 71.3 \\
\hline 5. Day-labor & 0 & .0 & 0 & .0 & 13 & 19.7 & 0 & .0 & 13 & 5.8 & 26 & 8.2 \\
\hline Total & 0 & .0 & 13 & 100.0 & 66 & 100.0 & 13 & 100.0 & 225 & 100.0 & 317 & 100.0 \\
\hline
\end{tabular}


Source: A survey of the author

Table 4 shows that there are 5 indicators but only indicator 3,4,5 with the number of workers selected. In indicator 4, verbal agreement accounted for the highest rate of $71.3 \%$, compared to indicator 3 , workers signing seasonal contracted accounted for $20.5 \%$ and indicator 5, workers have day-labor (no agreement) accounted for $8.2 \%$.

When comparing groups in term of seniority, there is a difference. In indicator 3, signing seasonal contracts, the group with seniority of 3-4 years accounted for the highest proportion of $100 \%$, the group with seniority of 1-2 years accounted for 39.4\% and the group with seniority of over 5 years represented $11.6 \%$. In indicator 4 , with verbal agreement, the group with seniority of 6 months- 1 year take the highest rate of $100 \%$ while the group with seniority of over 5 years accounted for $82.7 \%$ and $1-2$ years accounted for $40.9 \%$. It is clear that most of workers only sign verbal agreement or do daywork without agreement. When the author interviewed a male manager on Himlam construction site, he said: "If the project takes only 4 or 5 months to complete, we will choose the contract forms such as verbal agreement or day-labor".

In term of gender, there is a significant difference between groups. In indicator 3, signing seasonal contracts, female group accounted for $28.3 \%$, higher than the proportion of male group, that is $9.8 \%$. However, in indicator 4, verbal agreement, male group represented high proportion of $90.2 \%$ while female group accounted for $57.6 \%$. For day-labor, female group accounted for $14.1 \%$ while male group accounted for $0 \%$.

In term of marriage status, in indicator 3, signing seasonal contracts (under 12 months), the married group accounted for $23.3 \%$, compared to the unmarried group (14\%). In indicator 4 , the unmarried group accounted for $86 \%$ while married group represented $62.5 \%$.

Regarding household registration, age group and education level, there are also significant differences between groups.

The signing of labor contracts and collective bargaining agreements is one of the basic activities required for all types of enterprises, including the State-owned enterprises and the private ones. This is reflected in the legal documents issued by the State. However, most of the companies at Himlam construction site at present do not have an organization that protects the workers' rights. A male worker who was interviewed said that: "His company does not have a labor union, so it is unable to fulfill its commitments".

It is obvious that the characteristics of the jobs affect to the issue of signing labor contract. If jobs do not require a lot of industrial machinery and equipment, specialization, businesses can use the external labor force in order to save cost in the production process. Seasonal workers are absolutely not entitled to any social policies from enterprises as well as the State. For them, the immediate priority is to have a job to earn their living rather than paying attention to labor contracts or their rights. A female 32- year-old worker said that: "We are mostly in the countryside, so we have little understanding and no interest in labor contracts, being hired by the company and having a job makes us happy".

\section{EARNINGS}

Currently, the total income of the worker includes: contractual wages, overtime pay (hourly labor), Toxic money, attendance allowances, petrol allowances, housing, electricity and water allowances. The author's survey on the total income of workers at Himlam construction site is shown in the following table:

Table5: Total income of workers

\begin{tabular}{|c|c|c|}
\hline \multirow[t]{2}{*}{ Worker's Income } & \multicolumn{2}{|c|}{ Total } \\
\hline & $\mathrm{N}$ & $\%$ \\
\hline From 5.5 to 7 million VND & 67 & 21.1 \\
\hline From 7.1 to 9 million VND & 96 & 30.3 \\
\hline From 9 to 13.9 million VND & 154 & 48.6 \\
\hline Total & 317 & 100.0 \\
\hline
\end{tabular}

Source: A survey of the author 
Table 5 illustrates that the total income of workers at Himlam construction site from 9 million to 13.9 million VND takes the highest proportion of $48.6 \%$, the second is from 7.1 million to 9 million VND accounting for $30.3 \%$ and the lowest is from 5.5 to 7 million, accounting for $21.1 \%$.

The total income of the workers from different sources is presented below:

\subsection{Salary Income}

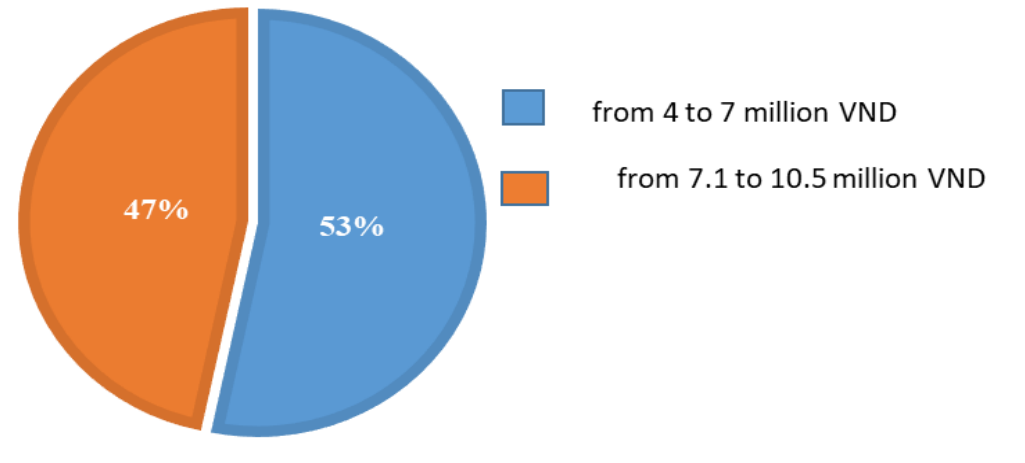

Chart3: Salary income

Source: A survey of the author

Chart 3 shows that currently, workers at Himlam construction site have salary income of VND 4 million to VND 7 million, accounting for 53\% higher than the group from VND 7.1 million to VND 10.5 million, accounting for $47 \%$. When comparing between social groups, there are also many differences between groups.

Table6: Salary income according to workers'jobs

\begin{tabular}{|c|c|c|c|c|c|c|}
\hline \multirow[t]{3}{*}{ Salary income } & \multicolumn{6}{|c|}{ Job } \\
\hline & \multicolumn{2}{|c|}{ Main worker } & \multicolumn{2}{|c|}{ Auxiliary worker } & \multicolumn{2}{|c|}{ Total } \\
\hline & $\mathrm{n}$ & $\%$ & $\mathrm{n}$ & $\%$ & $\mathrm{n}$ & $\%$ \\
\hline From 4 to 7 million VND & 1 & .8 & 168 & 86.6 & 169 & 53.3 \\
\hline From 7.1 to 10.5 million VND & 122 & 99.2 & 26 & 13.4 & 148 & 46.7 \\
\hline Total & 123 & 100.0 & 194 & 100.0 & 317 & 100.0 \\
\hline
\end{tabular}

Significant $=0.000$

Source: The survey of the author

Regarding the job of workers, there is a big difference. In indicator 1, from 4 to 7 million VND, auxiliary workers accounted for $86.6 \%$, higher than main workers $(0.8 \%)$. Meanwhile, in indicator 2, from 7.1 million VND to 10.5 million VND, the main workers accounted for $99.2 \%$ almost completely compared to the group of auxiliary workers of $13.4 \%$. When the author asked a male 46year-old manager at the Himlam site, he answered "A day's wage of a main worker depends on whether the worker is good or not. Their day's wage usually ranges from 300,000 VND to 500,000 VND, much higher than the auxiliary workers".

Regarding gender, there is a difference in salary income between male and female workers. In indicator 1, from 4 to 7 million VND, the female group accounted for $90.8 \%$, much higher than male group (1.5\%). In indicator 2, from 7.1 million to 10.5 million, the male group accounted for of $98.5 \%$, compared to the female group of $9.2 \%$. It is clear that the salary income of male workers is much higher than female ones. When the author interviewed a female worker at Himlam construction site, she answered: "We do not know to build like male workers, so we only do auxiliary jobs. The auxiliary jobs are mainly mixing mortars, carrying bricks"

In term of marriage status, there is a big difference between married and single group. In indicator 1, salary from 4 to 7 million VND, the married group accounted for $63.8 \%$ while single group accounted for $28 \%$. It is obvious that the married group have lower salary income than single group. To study about this issue, the author interviewed a female 44- year-old worker and her answer was that "Most of female auxiliary workers are married and they came here to work with their husbands. Their income is lower than the main worker, but it is much higher than growing rice". 
Regarding household registration, there is a relatively big difference between groups. In indicator 1 , salary from 4 to 7 million, the group with household registration outside Ho Chi Minh city accounted for $67.1 \%$ while the group with household registration in Ho Chi Minh city accounted for $8.1 \%$. A manager at Himlam construction site said that "The female auxiliary workers usually come from the west provinces". In terms of age, education level, there are also differences in salary income.

\subsection{Overtime Income}

The overtime income for workers working on Himlam is concentrated in two main income groups: the group with the overtime income of 500.000 VND to 1.5 million VND accounted for $68.6 \%$ while the group with overtime income of 1.6 to 3.2 million VND accounted for $31.4 \%$, as shown in the following table:

Table7: Overtime income according to gender

\begin{tabular}{|c|c|c|c|c|c|c|}
\hline \multirow[t]{3}{*}{ Overtime income } & \multicolumn{6}{|c|}{ Sex } \\
\hline & \multicolumn{2}{|c|}{ Male } & \multicolumn{2}{|c|}{ Female } & \multicolumn{2}{|c|}{ Total } \\
\hline & $\mathrm{n}$ & $\%$ & $\mathrm{n}$ & $\%$ & $\mathrm{n}$ & $\%$ \\
\hline 500 thousand- 1.5 million VND & 67 & 51.1 & 90 & 91.8 & 157 & 68.6 \\
\hline 1.6- 3.2 million VND & 64 & 48.9 & 8 & 8.2 & 72 & 31.4 \\
\hline Total & 131 & 100.0 & 98 & 100.0 & 229 & 100.0 \\
\hline
\end{tabular}

Significant $=0.000$

Source: A survey of the author

Table 7 shows that there is a significant difference in overtime income according to gender. In indicator 1, overtime income from 500 thousand to 1.5 million VND, the female group accounted for $91.8 \%$ while the male group accounted for $51.1 \%$. In indicator 2, overtime income from 1.6 to 3.2 million, the female group represented $8.2 \%$ while the male group accounted for $48.9 \%$. It is clear that the overtime income of female workers is much lower than male one. When the author interviewed a female worker, she replied that: "we only do auxiliary work, so we are paid low overtime income, with 30 thousand VND per hour"

When comparing between groups, there are differences in overtime income according to gender, marriage status, age and education level. There is a similarity between groups in term of household registration.

The allowances for housing, electricity and water are often supported by companies on the Himlam construction site, ranging from 1 to 1.5 million VND. In addition, there is currently no income from hazardous payments, attendance allowances, and petrol allowances even though the workers work very hard.

The following table shows spending of workers at Himlam construction site.

Table8: Spending rates of workers at Himlam construction site

\begin{tabular}{|c|c|c|}
\hline \multirow[t]{2}{*}{ Spending rate } & \multicolumn{2}{|c|}{ Total } \\
\hline & $\mathrm{n}$ & $\%$ \\
\hline Under 5 million VND & 303 & 95.6 \\
\hline 5-8.6million VND & 14 & 4.4 \\
\hline Total & 317 & 100.0 \\
\hline
\end{tabular}

Source: A survey of the author

Table 8 indicates that the current spending of most workers at Himlam construction site is less than 5 million VND a month, accounting for $95.6 \%$ while the spending from 5 to 8.6 million VND accounted for $4.4 \%$. It is obvious that he workers are very economical in spending. They mainly spend less than 5 million VND. They usually spend on meals, petrol, health care, children and phone call.

\section{CONCLUSION}

In summary, there are many problems regarding employment and income of female workers at Himlam construction site. They have to face many difficulties. One of the manifestation of these 
problems is that female workers are fired after a certain period of time. Enterprises on the construction site of Hilam project do not require workers with high skills. However, they require workers with good health. The female workers are often responsible for auxiliary work. Their work is repetitive and mechanical, and they usually have to work overtime, which have serious impacts on their health. Female migrant workers have less time working in the enterprises than local workers, so it is difficult for them to get a stable job. Wages of female workers in enterprises are low, and the minimum wage does not meet the minimum living standards of workers. However, the regular spending of migrant workers is always higher than that of local workers because they have to spend money on housing, transportation, medical care and sending money to support their family. Therefore, the government should issue more policies to support the employment and income of female migrant workers

\section{REFERENCES}

[1] Report on 10-year summary of Vietnam Trade Union implementing Resolution 20 / NQ-TW dated January 28, 2008 on continuing building Vietnam's working class in the period of promoting industrialization and modernization of the country.

[2] Summary report on 10 years of implementation of the Gender Equality Law and 10-year report on implementation of Resolution No. 11 / NQ-TW on the work of women in the period of stepping up industrialization and modernization of the country (Report of the Board of Women General Confederation in 2017).

[3] Urgent issues of the working class after 5 years of implementing Resolution 20 / NQ-TW "(2013 thematic report conducted by Assoc. Prof. Dr. Vu Quang Tho and Mr. Nguyen Manh Thang).

[4] Reproductive health care for female workers in industrial zones and the role of Trade Union (Ministrylevel project in 2012 of Women's Union General Department of Labor).

[5] Summary report on housing construction for workers of Ministry of Construction in the period 2010 2015

Citation: Doan Van Thang. "The Employment and Earnings of Female Workers at the Construction Site of Himlam Project, Tan Hung Ward, District 7, Ho Chi Minh City" International Journal of Research in Sociology and Anthropology (IJRSA), vol 6, no. 1, 2020, pp. 01-08. doi: http://dx.doi.org/10.20431/2454-867 7.0601001.

Copyright: (0) 2020 Authors. This is an open-access article distributed under the terms of the Creative Commons Attribution License, which permits unrestricted use, distribution, and reproduction in any medium, provided the original author and source are credited. 